\title{
FINANCING HEALTH CARE FOR THE AGED*
}

\author{
Lenore A. Epstein $\dagger^{\dagger}$ and James C. Callison $\ddagger$
}

\begin{abstract}
INTRODUCTION
The great medical advances of recent decades have made the cost and financing of health care for the aged a matter of national concern. In conjunction with our high and rising level of living, these advances are responsible both for the lengthened life span-which magnifies the problem-and for the widespread recognition that everyone should receive adequate medical care whether or not he can pay for it himself.
\end{abstract}

The aged population will almost surely grow to more than 20 million by 1970 , even without further advances in medical science. Today's 17 million aged 65 or older constitute nine per cent of the total population of the United States and fifteen per cent of those of voting age.

The health care needs of the aged as a group are much greater than those of a similar-sized group of younger persons. The effects of this increase in the volume of need are intensified by the rising costs of medical care. Modern medical services and drugs are very costly-much more effective, but still also much more costly than the best services available only a few decades ago. Yet in the face of this increased need for costly services the aged in general have lower than average financial resources. The problem which this creates for the aged has been accepted as a proper area for social concern and as representing a community responsibility. The issue has thus become one of the best ways to meet and to distribute the costs of adequate medical care for older persons.

Positions long staked-out were reiterated in July and August rg6r before the Committee on Ways and Means of the House of Representatives in two weeks of public hearings on the King-Anderson bill for health insurance for the aged, an Administration bill ranking high on President Kennedy's list of "must" legislation.

This paper will attempt to analyze, against a background of legislative history, the arguments of those who favor and those who oppose providing protection for

* The views expressed in this article are those of the authors and are not to be attributed to the Social Security Administration or the Department of Health, Education, and Welfare.

t A.B. 1935, Wellesley College; M.A. I937, Columbia University. Assistant Director, Division of Program Research, Social Security Administration, Department of Health, Education, and Welfare, Formerly Statistician, Economic Cooperation Administration; Economist, Prices and Cost of Living Division, Bureau of Labor Statistics. Author, Consumers Tangible Assets, in Studies In INCOME AND Wealthi (I950); Medical Care: Family Expenditure in Selected Cities, 1935-36 (1940); a series in the Social Sccurity Bulletin, including The Aged in the Population in 1960 and Their Income Sources (1961), Money Income of Aged Persons: A ro-Year Review, 1948-1958 (1959), Economic Resoturces of Persons Aged 65 and Over (1955).

$¥$ A.B. I95I, Oberlin College; Diploma 1958, Graduate School for Foreign Students, University of Copenhagen. Social Science Analyst, Division of Program Research, Social Security Administration, Department of Health, Education, and Welfare. 
the aged against hospital and related costs through the social security mechanism, and to identify the underlying issues involved in the decisions that Congress must make.

I

\section{LEgISLATTVE HISTORY}

\section{A. Perspective on the Issue}

Behind the present Administration's proposal for providing health insurance protection for aged persons eligible for old-age and survivors insurance or railroad retirement benefits lies a long developmental trail. The federal government, from the earliest days of its history, has assumed responsibility for medical services for selected groups of people. Special provisions for merchant seamen adopted in I792 laid the basis for a system of Marine Hospitals which later became Public Health Service hospitals. Since World War I, veterans have received care for service-connected disabilities and under certain circumstances for other disabilities as well. Members of the Armed Forces receive complete medical care; their dependents may receive care in federal facilities, and, to a limited extent, under Medicare, in civilian facilities. Other groups, including members of Congress, and Indians, are also entitled to medical care paid for by the federal government.

The federal and state governments jointly pay for some or all medical services for needy persons through the public assistance programs, and for special types of care such as services for crippled children, prenatal and well-baby clinics, and school health programs. Most mental and tuberculosis hospitals are supported by states or localities. Many of the states and localities also support general and special hospitals where care is provided free or at rates adjusted to the patients' income: Last year twenty-one per cent of all expenditures for personal health services were financed from public funds. This is slightly more than was met through private health insurance benefits.

In the period immediately preceding World War I, when workmen's compensation laws were adopted in a number of states, there was considerable interest in health insurance. Bills developed with the cooperation, at that time, of a committee of the American Medical Association were introduced in a number of state legislatures, but none were adopted.

The Committee on Economic Security, set up by President Roosevelt in I934, gave considerable attention to the need for a system of public health insurance but did not include in its Report specific proposals to that effect. The Social Security Act which was adopted in August r935 did, however, include provision for federal grants-in-aid to the states for public health activities, thus laying the basis for the development of modern public health programs in the United States.

Under the pressures of the war years, and in the face of divided public and professional opinion, Congress did not actually consider the issue of health insurance

${ }^{2}$ Merriam, Social Weifare Expenditures, Soc. Sec. Bull., November 1961, p. Io. 
until 1946. In November 1945, President Truman sent a special message to Congress, recommending a program of national health insurance as part of a long-range health program including more adequate public health services, additional medical research, a program of hospital construction, and aid to medical education. ${ }^{2}$ Federal grants to the states for hospital construction were provided in 1946; and over the years, funds for public health activities and medical research have been greatly expanded. The proposal for national health insurance was introduced as the WagnerMurray-Dingell bill, and the issue of health insurance was extensively debated in Congress during the years from I946 through 1950. National health insurance has not been an active political issue since then, but Representative Dingell, a son of one of the original bill's sponsors, re-introduces the proposal in each Congress ${ }^{3}$ more as a sentimental remembrance than a harbinger.

Among the significant factors leading to the demise of the proposed national health insurance program was the phenomenal growth of voluntary health insurance, first under the Blue Cross plans organized by hospital associations, and later through the Blue Shield associations organized by state medical societies and through insurance companies. The proportion of persons with hospital care insurance expanded from nine per cent of the civilian population in r 940 to fifty-one per cent in 1950 , with the percentage doubling between 1945 and $1950 .{ }^{4}$ In large part this rapid growth can be attributed to employer policies during World War II and to the priority given to programs of hospital and medical care at the bargaining table by labor unions. ${ }^{5}$ This meant that the growth in voluntary insurance was focused primarily on the labor force and its dependents.

Although more than seventy per cent of the total population now has insurance covering some or all of the costs of hospitalization, voluntary health insurance has been relatively unsuccessful in covering the low-income groups, including the aged, farmers (especially in the South), and migratory and domestic workers. The problem of the low-income aged, as a large and relatively identifiable group, has been singled out for attention. In I952, only twenty-six per cent of the aged-as opposed to fifty-nine per cent of those under 65-had hospital care insurance. ${ }^{b}$ Morcover, the private policies available for insuring the aged on an individual basis were by their nature expensive because of their relatively high utilization rates.

\section{B. Proposals Before the Eighty-Second to Eighty-Sixth Congresses}

To many who had earlier urged a national health insurance program, and to others as well, it seemed only logical to extend to the aged at least a minimum

\footnotetext{
"For a history of the developments leading up to this point, see Anderson, Compulsory Medical Care Insurance, 1910-1950, Annals, Jan. 1951, p. 106.

${ }^{2}$ See, for example, H.R. 4413, 87th Cong., Ist Sess., introduced Feb. I6, 196x.

¿U. S. Social Security Adm'n, Dep't of Health, Education, and Welfare, Division op Program Resenrch, Two Decades of Growth in Voluntary Henlth Insurance Enrollament; ReSEARCH AND STATISTICS note I7 (1960).

B Becker, Organized Labor and the Problem of Medical Care, Annals, Jan. 1951, p. I22.

- Falk \& Brewster, Hospitalization Insturance and Hospital Utilization Among Aged Persons, March 1952 Survey, Soc. Sec. Bull., Nov. 1952, p. $3 f$.
} 
hospital insurance benefit through a public program, to parallel the voluntary insurance coverage carried by the majority of the working population.

For this group, it was natural to look to the existing social insurance system and this led to the introduction in 1952 of three bills to provide hospital care benefits for old-age and survivors insurance beneficiaries. These bills were introduced in the House of Representatives by Representatives John Dingell and Emanuel Celler, and in the Senate by Senators Thomas B. Murray and Hubert Humphrey. ${ }^{7}$ These identical bills provided that aged persons eligible for benefits under the old-age and survivors insurance system, their dependents, and widows and children entitled to survivors benefits would be eligible for up to 60 days of semi-private room care in hospitals during any calendar year. There would be no retirement test, so that persons $6_{5}$ years of age or older who were eligible for cash benefits but not receiving them because they were still working would nevertheless be entitled to the hospitalization benefit. The hospital services covered under the program would cover all those services customarily provided by the hospital for its in-patients. It would include only those physicians' services which are generally furnished by hospitals as an essential part of patient care. In administering the program, the Federal Security Administrator (now the Secretary of Health, Education, and Welfare) would make agreements with the states to act as agents for the federal government, either in paying the hospitals for the care given beneficiaries according to a negotiated agreement, or in using nonprofit health insurance plans to deal with the hospitals. In those cases where a state would not enter an agreement, the federal agency would administer the program directly. Benefits were to be financed from the Federal Old-Age and Survivors Insurance Trust Fund.

Bills either identical or similar to this were introduced by a handful of congressmen in the Eighty-third, Eighty-fourth, and Eighty-fifth Congresses, but they were not received with any particular political gusto. ${ }^{8}$ Minor variations exist between the bills, as for example the encouragement to states to provide similar benefits for those aged persons not eligible for old-age and survivors insurance benefits, which was written into one bill.'

The change of Administration in 1953 was among the factors which tended to stifle any active attempt to provide health insurance under social security. In its early years, the Eisenhower Administration approached the problem of health insurance for hard-to-reach groups by recommending an underpinning of voluntary health insurance. In 1954, the Administration developed and sponsored a bill which

${ }^{7}$ H.R. 7484 , H.R. 7485 , and S. 300r, 82d Cong., 2d Sess. (1952).

${ }^{8}$ The bills introduced were: H.R. 8 (Mr. Dingell), H.R. 390 (Mr. Celler), and S. I966 (Senators Murray, Humphreys, and Lehman), 83d Cong., Ist Sess. (r953); H.R. 638 (Mr. Celler), and H.R. ${ }_{2384}$ (Mr. Dingell), 84th Cong., Ist Sess. (I955); H.R. 9868 (Mr. Dingell), and H.R. 9980 (Mr. Metcalf), 84th Cong., 2d Sess. (I956); and H.R. 1092 (Mr. Celler), H.R. 4765 (Mr. Dingell), and H.R. $944^{8}$ (Mr. Roberts), 85th Cong., Ist Sess. (I957).

S. r966, 83 d Cong., rst Sess. (r953). 
would establish a reinsurance fund to underwrite a large portion of the losses on reinsured contracts. ${ }^{10}$ Reinsurance was also the fundamental premise of a further Administration proposal in $1955^{11}$

Throughout the period when these proposals were being advanced, a groundswell of concern for the older citizens was developing. Proportionally, the number of persons 65 years of age or older was growing more rapidly than the population as a whole. ${ }^{12}$ Such a disproportionate increase in the number of the aged could be seen to continue well into the future. Rising from the increasing general concern for the older segment of the population, concomitant with what seemed almost a shocking increase in medical costs, has been the attention to the problems in financing health care for the aged.

The effective legislative progenitor of the current debate was Congressman Aime Forand, who introduced H.R. 9476 on August 27, 1957. This bill provided for increased cash benefits under the old-age, survivors, and disability insurance system and for health insurance benefits for persons eligible for monthly old-age and survivors insurance benefits. The provisions of the bill relating to health insurance deviated only in detail from those in the bills introduced earlier. The benefits were expanded to include surgical services and skilled nursing home services following hospitalization. In addition, administration was to be by the national government, using nonprofit agencies as might be found desirable. ${ }^{13}$ Although this bill differed in no significant degree from those introduced earlier, its introduction marks the effective, if not the chronological, beginning of intensive political argument on financing health care for the aged. Congressman Forand was at that time thirdranking majority member on the House Committee on Ways and Means, to which all social security legislation is referred. He introduced the bill late in the first session of the Eighty-fifth Congress to allow time for its consideration by individual congressmen before the second session. Thus, the bill was introduced by a high ranking member of the Committee charged with the matters which the bill encompassed, and for the express purpose of forcing Committee consideration of the issues which it raised. To add fuel to the political fire, the bill was rapidly endorsed by George Meany for the AFL-CIO, and was directly in line with the legislative objectives set by the American Public Welfare Association.

Public hearings before the Committee on Ways and Means of the House of Representatives were held on all aspects of the social security program from June 16 through June $30,195^{8}$. The health insurance provisions of the Forand bill were discussed by most of the witnesses testifying at these public hearings. The Com-

${ }^{10}$ H.R. 8356 (Mr. Wolverton), S. $31_{4}$ (Senators Ives, Flanders, Purtell, Cooper, Upton, Ferguson, Bush, and Saltonstall), 83d Cong., 2d Sess. (r954). For a brief description of the bills, see SEcnetAny of Health, Education, and Welfare, 86th Cong., ist Sess., Report on Hospitalization Insurance For OASDI Beneficiaries 106-07 (Comm. Print 1959).

${ }^{11}$ Id. at 107 .

12 The 1960 Census of Population shows an increase from 1950 to 1960 of $34.7 \%$ for persons aged 65 and over as compared with $18.5 \%$ for the total population.

${ }^{13}$ The bill's provisions are summarized in Mr. Forand's statement introducing the bill, x03 Cono. REc. 16769 (1957). 
mittee concluded, however, that more information was necessary before it could reach a meaningful decision. The Secretary of Health, Education, and Welfare was requested by the Committee to prepare a report on the practicability and costs of providing health care protection for older people through various alternative methods. Such a report was prepared and was submitted to the Committee on April 3, 1959. ${ }^{14}$ It not only explored alternative means for providing health care protection for old-age, survivors, and disability insurance beneficiaries, but also brought together data on the characteristics of the aged population, their use of medical care services and facilities, and their coverage by voluntary health insurance.

In July 1959, the Ways and Means Committee, under pressure from Representative Forand, held a week of public hearings on H.R. 4700, the Forand bill for health insurance for old-age and survivors insurance beneficiaries. The bill was a slight modification of the health insurance provisions in H.R. 9467 as considered by the previous Congress. In testifying on the bill, the Secretary of Health, Education, and Welfare, Arthur S. Flemming, recognized the existing need for a more satisfactory solution than presently existed to the problem of paying for adequate medical care for the aged. However, Secretary Flemming held that H.R. 4700 did not provide a satisfactory solution to the problem, since he believed that so far as possible reliance should be placed upon and encouragement given to individual and organized voluntary action. During the hearings, numerous witnesses testified both for and against providing health insurance for the aged through the social insurance mechanism. Among these supporters were the American Federation of Labor-Congress of Industrial Organizations, the American Public Welfare Association, the American Nurses Association, Group Health Association of America, the Physicians' Forum, and the National Association of Social Workers. Those opposing the proposal included the American Medical Association, a number of state and county medical societies, the American Hospital Association, the Chamber of Commerce of the United States, the Health Insurance Association of America, the American Life Convention, and the Life Insurance Association of America. Since the arguments advanced both by those in favor of and opposed to the use of the social insurance system have remained essentially unchanged throughout the consideration of the issue, they will be considered later in analyzing the problem of financing health care for the aged rather than in connection with specific testimony.

\section{Congressional Activity in I960}

The second session of the Eighty-sixth Congress saw a substantial increase in the tempo of consideration of health insurance for the aged. The mail poured in on the members of Congress; numerous newspapers and magazines examined the issue, and some took a stand; congressmen read into the Congressional Record the articles and editorials, along with other speeches and comments. In part, this reflected increasing

\footnotetext{
"Secretary of Health, Education, and Welfare, 86th Cong., ist Sess., Report on Hospitalization Insurance for OASDI Beneficiaries (Comm. Print 1959).
} 
public concern over health costs for the aged; in part, it reflected organized campaigns by both the proponents and opponents of health insurance for the aged under the social security system. The state and local conferences held in preparation for the White House Conference on Aging aroused further interest in health insurance for the aged. Hearings throughout the country by the Subcommittee on the Problems of the Aged and Aging, created by the Senate in February 1959 to "examine, investigate, and make a complete study of ... the problems of the aging,"15 also fanned interest in the health financing problems of the aged.

On March I4, xg60, the Ways and Means Committee began executive session consideration of possible amendments to the Social Security Act. These sessions were continued into June, with a large part of the time devoted to medical care.10 While the Committee deliberations were under way, Secretary Flemming was attempting to develop a compromise program to meet the health costs of the aged which was not based on the social security system. Although Mr. Flemming was hard pressed to find a program acceptable to the disparate elements of the Republican Party, the Committee on Ways and Means held up action until an Administration proposal was presented. In large part, the willingness of the Committee to wait as long as it did (Secretary Flemming was unable to present an Administration proposal until May 4) can be attributed to the lack of any majority support for the use of the social insurance approach. Throughout the period there were only eight supporters of the Forand bill in the twenty-five member committee. With interest growing in health care for the aged, the Committee was intent upon considering all proposals.

While the Committee on Ways and Means was deliberating and Secretary Flemming was attempting to develop an Administration proposal, several new bills were introduced in the Senate. The bills which had been earlier introduced in the Senate ${ }^{17}$ were identical to the Forand bill or paralleled it with relatively minor changes in benefits or coverage. Those newly introduced branched somewhat more afield.

Senator Jacob J. Javits, speaking for himself and seven other liberal Republican senators, and apparently impatient with the delay in developing an Administration bill, on April 7 introduced as S. $335^{\circ}$ the liberal Republican proposal for health care for the aged. Identical bills were introduced by six members of the House of Representatives. They would have established a Federal grant-in-aid program to help the States subsidize health insurance protection for persons aged 65 and older. This bill differed in almost all essentials from the Forand bill and from the viewpoint generally adopted by those espousing the so-called social security

${ }^{15}$ S. Res. 65, 86th Cong., Ist Sess. (1959).

${ }^{10}$ For a more complete description of health insurance for the aged consideration by the Eighty-sixth Congress, see Mitchell, Social Security Legislation in the Eighty-sixth Congress, Soc. Sec. Bull., Nov. 1960, p. 5, and F. J. Seidner, Health Insurance for the Aged 33-59 (1960).

${ }^{17}$ S. 881 (introduced by Senator Wayne Morse), S. II5I (introduced by Senator Hubert Humphrey), 86th Cong., Ist Sess. (1959), and S. 2915 (introduced by Senator John Kenniedy for himself and Senator Philip Hart), 86th Cong., 2d Sess. (I960). 
approach. Under the Javits proposal, the federal government would provide moneys to the states in order to assist them in providing health insurance for aged persons. The government share, both federal and state, would be financed from general revenues. Participation both by aged persons and by states would be voluntary, that is, states would not be required to establish a program, and individuals would not participate unless they paid an annual subscription ranging up to $\$$ m 3 per month or such larger amounts as the state might designate. Benefits were concentrated on diagnostic and early short-term care rather than upon the major costs of long illness. Thus, the support of this group was thrown on the side of preventive short term care. Moreover, under this proposal all aged in the participating states would be eligible, not only those receiving monthly social insurance benefits. Individual contributions were to be adjusted, so that the larger the income of an aged individual, the greater the proportion of the cost he would pay. Persons with annual incomes of $\$ 3,600$ and above were expected to pay the full premium cost of the protection.

On May 4, Ig60 Secretary Flemming unveiled the Administration's proposal before the House Ways and Means Committee and released it publicly. ${ }^{18}$ This proposal followed the general lines of that advanced by Senator Javits, except that it concentrated on catastrophic and expensive illnesses rather than upon early preventive and diagnostic services. It provided for federal grants-in-aid to the states to help finance a health insurance program for persons aged 65 or over who did not pay an income tax in the preceding year or who had an adjusted gross income plus social security, railroad retirement and veterans' benefits which did not exceed $\$ 2,500$ ( $\$ 3,800$ for a couple), and who paid an annual enrollment fee of $\$ 24$. The enrollment fee was to be waived for old-age assistance recipients. The proposal provided for both deductible and coinsurance features under consideration by the Administration for some time. Thus, the insured person would be required to meet the first $\$ 250$ of medical expense in any year, and the insurance program would meet eighty per cent of the costs of essentially all health and medical services beyond that. The proposal also incorporated an "opting out" provision, in line with the Administration's interest in supporting the attempts of voluntary health insurance to extend adequate coverage to aged persons. Thus, persons eligible for the Government program who so wished could receive fifty per cent of the cost of a private insurance policy, up to a maximum of $\$ 60$ a year, in lieu of the benefits provided in the Government plan.

On the heels of the Administration proposal, Senator McNamara introduced, for himself and eighteen others, S. 3503 , a bill designed to meet several of the criticisms which had been directed at the Forand bill. ${ }^{19}$ Among the major criticisms of the Forand bill, and of the use of the social insurance system in general, had been the fact that a large number (at the time an estimated 4 million out of 16 million

\footnotetext{
${ }^{18}$ Statement by Arthur S. Flemming, Secretary of Health, Education, and Welfare, before the House Ways and Means Committee, May 4, 1960.

${ }^{10}$ See Mitchell, supra note 16.
} 
aged persons) would not be covered under the program. The McNamara bill dealt with this issue squarely by extending benefits to all aged persons (other than those entitled to federal civil service or railroad retirement benefits), financing benefits for social security beneficiaries through an increase in the payroll tax, and benefits for those not eligible from federal general revenues. The bill declared it congres ${ }^{2}$ sional policy to establish similar programs for railroad retirement and federal civil service retirement beneficiaries. It also introduced a retirement test, so as to hold down the number of aged persons who would be eligible for health insurance while still employed, and excluded younger beneficiaries under the old-age, survivors, and disability insurance system. Finally, the benefit structure proposed was altered so as to place more emphasis on out-of-hospital care.

Essentially, despite the variations among specific proposals, the House Ways and Means Committee had before it in mid-xg6o three major alternatives: (I) to establish basic health insurance for the aged through an extension of the social insurance system; (2) to provide for a federal grant-in-aid program to assist the states in establishing protection for their aged citizens; or (3) to reserve judgment as between these two approaches but move to take care of the most pressing needs by providing some federal funds to help meet the needs of the medically indigent aged. It was this last course that was resolved upon by the Committee. After rejecting various modifications of the Forand bill, the members worked out a program similar to the existing public assistance programs, but with a less stringent test of need.

The Social Security Amendments of rg60, H.R. I2580, were reported out by the Committee on June 13 and included, as a separate title of the Social Security Act, a program for federal grants to the states to share in the costs of meeting medical expenses for those aged persons who needed such assistance. There were some limits on the services in the cost of which the federal government would share, but these were so high that they would affect few cases. The amendments were considered in the House under a closed rule and were passed, 38I to 23.

The Senate Finance Committee held public hearings on the bill as passed by the House on June 29 and June 30 . Essentially no one objected to the proposed assistance progam as it had passed the House. The advocates of both the social security approach and the grant-in-aid for insurance approach pointed out, however, that the bill adopted by the House did not meet the basic need, and repeated the advocacy of their own particular solutions. The Committee, after executive consideration, followed the general route traversed by the Ways and Means Committee. Instead of a separate title, the amendments reported by the Senate Finance Committee established the program for aged medically indigent as part of Title I of the Social Security Act, which deals with the old-age assistance program. In addition, the Committee provided for additional federal matching funds as an incentive to states to improve their medical care programs for old-age assistance recipients.

The Senate Finance Committee reported out H.R. r2580 with its amendments 
on August 19, when Congress had resumed sessions after the recess for the nominating conventions. The political atmosphere was charged to an even greater extent than it had been before, because both presidential candidates were involved in the Senate proceedings. Both conventions had adopted platform planks espousing federal action to assure health care protection of older persons. The Democratic platform promised to "provide an effective system for paid up medical insurance upon retirement, financed during working years through the social security mechanism and available to all retired persons without a means test."20 The Republican platform statement was ambivalent as to the line of action recommended, pledging the party to the "development of a health program that will provide the aged needing it, on a sound fiscal basis and through a contributory system, protection against burdensome costs of health care."21

When H.R. $125^{80}$ reached the Senate floor, the three possible approaches which had been before the House Ways and Means Committee and the Senate Finance Committee were debated. Senator Javits introduced an amendment which combined his earlier proposal with that of the Administration. After several hours' debate, the Republican measure was defeated, 67 to 28 , on a straight party vote. The adherents of the social security approach had agreed on the Anderson-Kennedy amendment as the proposal which they would support on the Senate floor. This amendment, a modification of an earlier amendment, introduced by Senator Anderson, would have provided certain hospital, skilled nursing home, home health care, and hospital outpatient diagnostic benefits for old-age and survivors insurance beneficiaries aged 68 and over. The amendment was defeated by a vote of $5^{I}$ to 44 . Thus, the Senate was not able at this particular juncture to resolve through the political process the question as to how to provide health protection for the aged.

\section{After the Ig60 Election}

Debate on the issue was carried to the hustings during the presidential campaign, where it was one of the major differences on domestic policy between the two parties. Upon his election, President-elect Kennedy included the provision of health insurance for the aged through social security in his list of priority legislation. For further exploration of this problem and others in the health and social security fields, he appointed a task force, headed by Wilbur J. Cohen. This Task Force, reporting on January Io, I96r, recommended a health care program with benefits paralleling those in the Anderson-Kennedy Amendment but with eligibility extended to insured persons aged $6_{5}$ and over (rather than 68).

The White House Conference on Aging, meeting in Washington, D. C. from January 9 to $12,196 \mathrm{r}$, had as one of its focal points the question of financing health care for aged persons. The Income Maintenance Section, which included financing

${ }^{\infty}$ Democratic Party, Comm. on Resolutions and Platform, The Democratic Platform: The Rugirts of MAN 33 ( 1960$)$.

${ }^{21}$ Republican Party, Comm. on Program and Progress, Decisions for a Better America 23 (1960). 
health costs, recommended by a vote of 170 to 99, "that the Social Security mechanism should be the basic means of financing health care for the aged." The Section reported that "private voluntary effort and public assistance can contribute much to the solution of the problem," but that, "they will continue to fall short of meeting the basic medical care needs of the aged as a whole."22

Within three weeks after his inauguration, on February 9, President Kennedy sent to Congress a special message on a health program which called for action in the fields of medical facilities and personnel, research, health care for children and youth, and vocational rehabilitation, as well as health insurance for the aged under social security. Draft bills on a number of these subjects were sent to both the House and the Senate. ${ }^{23}$ The Administration-sponsored legislation on health insurance for the aged was introduced as S. gog by Senator Anderson, on behalf of himself and sixteen other senators, and as H.R. 4222 in the House by Representative Cecil King, second ranking member of the House Ways and Means Committee. Nine identical bills were introduced in the House.

Senator Javits, on behalf of himself and nine other Republican senators, re-introduced as S. 937 his amendment to H.R. 12580 from the year before, primarily to reinforce the emphasis which he felt should be placed on preventive medical care, protection of the aged not covered by social security, flexibility for the states to improve the program, and a cash option for those who prefer voluntary health insurance. $^{24}$ Senator McNamara had previously re-introduced as S. 65 the bill which he had supported in the Eighty-sixth Congress.

Throughout the congressional session there had been some question as to how rapidly the House Ways and Means Committee would consider health insurance for the aged. Senator Javits in particular was insistent in his demand that something should be done during the session. ${ }^{25}$ In May, Chairman Wilbur Mills of the Ways and Means Committee promised to hold public hearings after the Committee completed consideration of the President's tax message. These hearings were held between July 24 and August 4. The session ended without the Committee reporting a bill.

In an exchange during the closing days of the Congress, Senator Javits again

22 U. S. Dep't of Health, Education, and Welfare, Special Staff on Aging, The Nation and Its Older People, Report of the White House Conference on Aging i29 (1961).

23 The Administration-sponsored Community Health Services and Facilities Act, 75 Stat. 824, signed by the President on Oct. 5, I96I, recognized that while the proposed health insurance program would itself stimulate more facilities and services, communities need additional help to provide adequate health services. It attacks the problem of the chronically ill and aged, by providing construction grants for nursing homes, stimulating grants to the States to improve health services outside the hospital, and hospital research grants. To foster research in the areas of child health and human development, a Child Health Center has been set up in the Division of General Medical Services at the National Institutes of Health, and the Administration has proposed legislation for the creation of a new Institute of Child Health and Human Development. The Administration has also proposed a program of federal assistance to medical education.

${ }^{24}$ ro7 CoNG. REc. I990-9I (I96I).

${ }_{35}$ For example, see his exchange with Senator Anderson during the Senate floor consideration of the Social Security Amendments of 1961. I07 CoNG. REC. I0519-22 (I96I). 
criticized the tortoise-like progress of health insurance for the aged on the Senate floor. ${ }^{28}$ Senator McNamara released a letter from the President emphasizing the high priority he placed on health insurance for the aged in the second session legislative program. ${ }^{27}$ On October 2, Senator Javits, in a speech before the panel organized by Group Health Insurance, Incorporated, in New York, publicly announced his support for a compromise proposal incorporating the benefits under his bill, but financing them for old-age and survivors insurance beneficiaries through an increase in the payroll tax. ${ }^{28}$

\section{E. The Kennedy Administration Proposal}

Under the King-Anderson bill for health insurance for the aged, certain hospital care, skilled nursing home care, home health care, and outpatient hospital diagnostic services would be financed for persons aged 65 and over who are entitled to oldage, survivors, and disability insurance or railroad retirement benefits. Persons would be eligible for health benefits even if they were still working and therefore not receiving monthly cash benefits. Although the use of the contributory social insurance system does not make the health program available to all the aged, it is estimated that about ninety-five per cent of the present labor force will be entitled to benefits when they reach the age of $65 .{ }^{29}$ Those not so protected would largely be federal government employees (who have their own health insurance plan), self-employed physicians, and the state and local employees not under social security.

The plan would also cover a great majority of the present aged, since health benefits would be provided for all aged presently eligible for social insurance cash benefits. It was estimated that at the beginning of $I 96_{3}, I_{4} 1 / 4$ million of the $I 73 / 4$ million persons aged 65 or over would be eligible for the protection. ${ }^{30}$ According to the Secretary of Health, Education, and Welfare's testimony before the House Ways and Means Committee, this pattern of immediate coverage of those who worked under the program in the past is in "the tradition that has been followed from the beginning of the program."31

Under the program, beneficiaries would be eligible during a period of illness for up to 90 days of inpatient hospital services (subject to a deductible contribution by the patient), including bed, board, nursing services, and other supplies and services customarily furnished by a hospital; and up to I80 days of skilled nursing home care following discharge from a hospital and for the condition for which the beneficiary was hospitalized. Both hospital and skilled nursing home care are subject to an over-all limitation of 150 units of service during a period of illness, with either

${ }^{\infty}$ Id. at $16928-32$.

${ }^{27} I d$. at I7I74-75.

${ }^{23}$ N. Y. Times, Oct. 3, 196r, p. 3I, cols. I-4.

$\approx$ Statement by Abraham Ribicoff, Secretary of Health, Education, and Welfare, before the House Committee on Ways and Means, in Hearings Before the House Committee on Ways and Means on Health Services for the Aged Under the Social Security Insurance System, 87th Cong., Ist Sess. 33 (I96I) [hereinafter cited as Hearings].

${ }^{30}$ Id. at 33 .

IId. at 34 . 
one hospital day or two skilled nursing home days equal to one unit of service. Thus, a person who spent up to 60 days in the hospital would be entitled to the full maximum of 180 skilled nursing home days. A person using the maximum hospital benefit would be eligible for I20 days of skilled nursing home care during a period of illness. As defined in the bill, after hospitalization a new period of illness begins only when 90 days have elapsed during which the beneficiary was neither a hospital inpatient nor a patient in a skilled nursing home. The individual receiving inpatient hospital services must pay toward the costs of such care a deductible contribution of $\$$ Io a day for the first 9 days, with a minimum deductible amount of $\$ 20$.

In addition to inpatient hospital and skilled nursing home care, the program would pay for home health services furnished under a plan prescribed by a physician, up to a maximum of 240 home health service visits a calendar year. These services could include nursing care, physical, occupational and speech therapy, medical supplies (other than drugs) and appliances for temporary use, and, as permitted in regulations, part time or intermittent home-maker services. The program would also pay for outpatient hospital diagnostic services, subject to a $\$ 20$ deductible contribution per diagnostic study.

These benefits provided under the program are institution-oriented. Essentially, the benefit is a hospital care benefit, with such added supplementary benefits as will allow the most economical use of hospitals when the individual's condition does not require the intensive care available in a hospital. However, not all necessary medical services are covered by the insurance. The only physicians' services which would be covered under any of the four basic benefits are those which bear an intimate relationship to the inpatient hospital benefit. 'Thus, physicians' services would not be covered except for services in the fields of pathology, radiology, physical medicine, anesthesiology, and services rendered by interns and residents-in-training. Services in mental and tuberculosis hospitals are excluded, as, in general, are those in federal hospitals.

The bill as introduced in early I96I provided that the program would start with respect to inpatient hospital, outpatient hospital diagnostic, and home health services on October I, I962. Skilled nursing home benefits were to begin on July 1,1963 . These dates were premised upon the enactment of legislation during the first session of the Eighty-seventh Congress. Since this did not come about, the important thing to note is that under the President's program about one year's lead time was allowed between enactment and the commencement of benefits for the major portion of the program. However, a time of one and a half years was considered necessary to set up the necessary machinery for a skilled nursing home benefit.

The administrative machinery and the requirements for participating providers of service which are set forth under the program require this tooling-up period. The Secretary of Health, Education, and Welfare, in whom the administrative authority is lodged, must not only establish internal records so that beneficiaries may be identi- 
fied and their use of benefits recorded, ${ }^{32}$ but he must also enter into agreements with those providers of service who meet the conditions of participation so that they will be paid the reasonable costs of the services performed.

The qualifications for providers of service are set forth in the Adminstrationsponsored bills. Essentially, these conditions are those generally accepted as being essential to a reasonable quality of care. For example, among other conditions hospitals and skilled nursing facilities must provide 24-hour nursing service and maintain adequate medical records. Similarly, home health agencies must be primarily engaged in providing skilled nursing or other therapeutic services. ${ }^{33}$

The Secretary would be assisted in the administration of the program by a Health Insurance Benefits Advisory Council, which would advise him on matters of general policy. The Secretary would also consult with appropriate state agencies and recognized national licensing or accrediting bodies in formulating the conditions for participation by providers of services.

In administering that part of the program calling for certification of providers as meeting standards, as well as in providing consultative services to providers to assist them to meet the conditions for participation, it is anticipated that state agencies would be used as much as possible. Indeed, to safeguard state standard-setting activities, the Secretary would have the authority to accept state recommendations for higher conditions of participation by providers within that state than are applicable nationally. In addition, the Secretary would have authority to accept accreditation of an institution by a national accrediting body as prima facie evidence that the institution meets any or all of the requirements for participation.

This program would be financed by an increase in the social security payroll taxes. When first introduced in Congress, the estimated average annual cost of the program on a level premium basis was 60 per cent of taxable earnings. The tax increase provided for in the proposal was set at a level to equal this annual average cost, estimated into perpetuity. This meant a tax increase of $1 / 4$ of one per cent each on employers and employees, and $3 / 8$ of one per cent on the self-employed, plus an increase in the maximum earnings subject to the tax from $\$ 4,800$ to $\$ 5,000$. The increase in the earnings base from $\$ 4,800$ to $\$ 5,000$ was scheduled for taxable years ending after I $66 \mathrm{r}$, and the tax increase was to apply to taxable years ending after Ig62. However, in the period after the introduction of the measure and before the public hearings, a reevaluation of the level premium costs by the Chief Actuary of the Social Security Administration indicated that the estimates were too low for the skilled nursing home and home health benefits and somewhat too high for the hospital inpatient and outpatient diagnostic benefits. His revised estimate of the cost for the program was .66 per cent of taxable earnings. ${ }^{34}$ To meet this estimated increased cost, Secretary

${ }^{3}$ A description of the proposed plan of operation is found in the report submitted to the House Committee on Ways and Means by the Secretary of Health, Education, and Welfare, entitled Health Insurance for Aged Persons, in Hearings I44-6r.

${ }^{33}$ For greater detail, see Health Insurance for Aged Persons, in Hearings 13I-37.

${ }^{34}$ For a fuller description of estimating techniques and of costs, see RoBert J. MYers, Actuariar Cost 
Ribicoff recommended that the tax rate remain unchanged, but that the earnings base be increased from $\$ 4,800$ to $\$ 5,200$, rather than to $\$ 5,000 .^{85}$

The estimated level premium costs for the various benefits, stated in terms of a percentage of taxable payroll, are: inpatient hospital care, .52 per cent; skilled nursing home care, .08 per cent; home health services, .05 per cent; and outpatient hospital diagnostic services, or per cent. Stated in terms of dollars, the outgo for benefit payments and accompanying administrative expenses in calendar year 1963 was estimated at $\$ 1,062$ million. ${ }^{86}$

\section{II}

\section{The Statistics Behind the Argument}

Now that few deny a national interest in the provision of health care for the aged and the issue has rather become one of the proper scope for a public program, it no longer seems useful to dwell at length on the evidences of the need for a program. However, since some of the same data are relevant to the question of scope, it may be well to examine briefly how the costs of health care are met at the present time, and the indications that there is unmet need for care. Reports on the health status and the socio-economic characteristics of older persons, on the one hand, and the nature and extent of present provisions for meeting their medical costs are the raw data. They have been assembled and analyzed in the report entitled "Health Insurance for Aged Persons" which Secretary Ribicoff submitted to the House Committee on Ways and Means on July 24, I96r. This section draws heavily on the materials presented in that Report. ${ }^{37}$

\section{A. How Health Care Costs of the Aged are Met}

In his testimony, the Secretary of Health, Education, and Welfare emphasized the fact that the Government is already involved on a substantial scale in meeting the cost of personal medical care, especially for the aged, but for other groups in the population as well. Of the $\$ 23.7$ billion spent in this nation for personal health care in fiscal year Ig60, 20.6 per cent was from public funds.

Of some $\$ 5$ billion estimated to be spent for the medical care of persons aged 65 and over at this time, well over one-fifth is financed from public funds, and a small proportion out of formal philanthropic contributions. This means that no more than three-fourths of the medical care purchased for the aged is paid for by those receiving the care, their relatives or friends, either directly or through voluntary insurance.

Estimates for Heaith Insurance Benefits Bill (U.S. Social Security Adm'n, Dep't of Health, Education, and Welfare, Division of the Actuary, Actuarial Study No. 52-r, I96r).

${ }^{3}$ Hearings 32-33.

${ }^{20}$ MYERs, op. cit. supra note 34 , at 70-71.

${ }^{37}$ See especially Part I. In the interest of brevity, specific documentation is provided only for data not included therein. For a fuller discussion of such material in the context of the total medical care problem, see Herman M. \& Anne R. Somers, Doctors, Patients, and Health Insurance (ig6r). 
Some "free" care has traditionally been provided to the needy both by physicians and nongovernmental hospitals. In testimony on H.R. 4222 before the House Committee on Ways and Means on August 2, the American Medical Association cited a figure of $\$ 65^{8}$ million as the annual value of services provided free by physicians to needy persons of all ages. ${ }^{38}$

In the case of voluntary hospitals, the value of "free" care provided from the hospitals' own resources has been estimated at \$180 million in I959 on the basis of uncollected charges. ${ }^{39}$ While the cost of care provided to the needy without charge or at reduced fees is occasionally financed from endowment income and philanthropic sources, it is likely to be defrayed by higher charges to the patients who pay. Thus, at least part of the needed care is financed by persons who are themselves facing a heavy burden of medical costs and at a time when their own incomes may be reduced because of illness. In a like fashion, part of the cost of health insurance for the aged who are fortunate enough to be covered by Blue Cross plans with community-rated premiums is paid by the working population. ${ }^{40}$

Thus, while the cost of much of the needed care is at present met by public funds and private philanthropy, some of the social costs are paid through the illness and misery of those who cannot pay for their own care and for one reason or another do not obtain care without charge. In other words, there is unmet need for medical care.

While the magnitude of this need cannot be measured with any precision, we do know that financial barriers restrict the use of medical services. We know that the use of most types of care is correlated with income, and that at every income level persons with health insurance are more likely to receive hospital care than those without. The medical aid that is now provided for the needy (other than veterans) varies from place to place and much of it is available only on terms which lead many old persons to forego services rather than subject themselves or their children to a means test which they regard as degrading.

\section{B. Evidence of Unmet Need}

\section{r. Health Characteristics and Use of Physicians' Services}

Arthritis, rheumatism, heart disease, and high blood pressure cause much of the disability in later life. According to findings of the National Health Survey for the noninstitutional population, persons 65 and over are six times as likely as younger persons to suffer a chronic limitation of their activity and thirteen times as likely to be limited in physical mobility.

The fact that this survey does not include persons in homes for the aged, nursing homes, and long-stay hospitals and other institutions means that the health situation

${ }^{2}$ Hearings 1372 .

${ }^{20}$ U.S. Dep't of Health, Education, and Welfare, Medicat Resources Avaizable to Meet the Needs of Public Assistance Recipients 70 (1961).

${ }^{\circ 0}$ Community rating as a cost sharing device is not entirely successful, however; it has weakened the competitive position of plans using it and is giving way increasingly to experience rating. 
of older persons is in fact more unfavorable than the survey data suggest, particularly in comparison with younger persons. Moreover, many believe that medical diagnosis would reveal more serious conditions than are reported in household interviews.

The number of days on which activity is restricted, because of acute illness or injury as well as chronic disability, is $2^{1 / 2}$ times as large for those 65 and over ( 43 days) as for those younger ( 17 days), and the number of days of confinement to bed is double ( 14 for those over 65 and 7 for others).

Aged persons obviously require many health services, and they do utilize more services, on the average, than younger persons. They consult a physician about 6.8 times per year, on the average, compared to a rate of 4.8 consultation for persons under 65. It is striking, however, that while there is little change after age 45 in the use of physicians' services by active persons, for persons with limitations the use of physicians' services decreases with advancing age. For those with major limitation of mobility, for example, the average annual number of physician visits in x957-59 dropped sharply from 35 per person, on the average, for the $45-$ to- 54 year age group to 18 for those 75 and over.

Various factors may contribute to this apparent anomaly. The availability of resources to finance care would certainly be an important one. For the population as a whole, the lower the income the greater is the incidence of disability and the less the likelihood of receiving care. Persons 65 and over living as members of families whose income was less than $\$ 2,000$ in $1957-59$ had an average of 6.5 physician visits per year, while those in families with incomes of $\$ 7,000$ or more consulted a physician 8.7 times per year on the average. This difference is in contrast to the fact that, as shown by the following figures, the former were more likely than the latter to suffer chronic limitations on activity or mobility.

\section{TABLE I}

Aged Persons

with Limitation of

Family Income Physical Mobility (percentage)

Under \$2,000 $\$ 7,000$ and Over

$2 I$

I7
Aged Persons

with Limitation of Activity (percentage)

48

37

Within each of the activity limitation categories, the frequency of physician visits was directly correlated with the size of family income.

These data certainly suggest that there is unmet need for medical care. The contrasts would probably be sharper if similar data for aged persons were available by an income classification in terms of adult-equivalent units. The smaller their resources and the more serious their health problems, the more likely older persons are to share a home with relatives. 


\section{Hospital Utilization}

Older persons go to the hospital more frequently than younger persons (including maternity cases) and stay almost twice as long, on the average. This is shown by the following figures from the National Health Survey for persons discharged from short-stay general hospitals in I958-60:

\section{TABLE II}

\begin{tabular}{|c|c|c|}
\hline & $\begin{array}{l}\text { Persons } 65 \\
\text { and Over }\end{array}$ & $\begin{array}{l}\text { Persons } \\
\text { Under } 65\end{array}$ \\
\hline Annual discharges per I00 persons. & $\ldots .14 \cdot 6$ & $I x .2$ \\
\hline Average length of stay in days..... & $\ldots 14.9$ & 7.6 \\
\hline Aggregate days per Ioo persons. & $\ldots 218$ & 85. \\
\hline
\end{tabular}

Because some persons are hospitalized more than once during a year, the number of persons hospitalized is somewhat smaller than the number of discharges per person.

A national survey of old-age and survivors insurance beneficiaries conducted in late 1957 found somewhat more days of general hospital care per year than the National Health Survey for persons $\sigma_{5}$ and over-236 as compared with 2I8 per Ioo aged persons. The difference stems in part from the fact that the National Health Survey includes aged persons in the labor force, who are less likely to be hospitalized than the retired; and in part from the fact that this survey is restricted to the noninstitutional population, whereas the beneficiary survey included time spent in a general hospital by persons who were otherwise in an institution.

However, all figures developed from household interviews understate utilization, because they exclude the hospital experience during the survey year of persons who died prior to the interview. The differential between the aged and the rest of the population would of course be greater if the hospital days of decedents were reflected.

In contrast to the finding as to consultation of physicians, available data on hospital utilization of old-age and survivors insurance beneficiaries at different income levels indicate that the probability of an aged person entering a hospital bears little systematic relationship to his income. At each income level, however, those beneficiaries with some health insurance tended to have a higher hospital admission rate than beneficiaries with no insurance.

In general, persons who have health insurance enter hospitals more frequently but have shorter average stays than those who are uninsured. As indicated by the following table, the National Health Survey for July-December 1959 shows that regardless of sex or age, older persons with health insurance are much more likely than other aged persons to have one or more short-stay hospital episodes in a year. ${ }^{41}$

\footnotetext{
1 U.S. National Health Survex, Public Health Service, Interim Report on Health INsurance, Henlth Statistics Ser. B, No. 25 (1959).
} 
TABLE III

Sex AND Age

Total $6_{5}$ and over

Men 65-74

75 and over

Women $65-74$

75 and over
One or More Hospital Episodes

(Percentage)

$\begin{array}{cc}\text { Insured } & \text { Not insured } \\ 13.7 & 8.3 \\ 13.3 & 9.7 \\ 15.5 & 9.1 \\ 12.5 & 7.8 \\ 17.0 & 6.5\end{array}$

\section{Incomes}

Withdrawal from the labor force with advancing age brings substantial reduction in income to most older persons. Income statistics from the Bureau of the Census for 1960 show that fifty-three per cent of the persons $6_{5}$ and over not in institutions had cash incomes below $\$ 1,000$ in that year. While these income data for persons do not indicate how many persons depend on their incomes, it is clear that some of the income attributed to a married man goes for support of his wife. Three-fifths of all the men reported less than $\$ 2,000$ in 1960 . Wives who are dependent on their husbands are of course shown as having little or no income. However, only about one-fifth of all persons $6_{5}$ and over are married women. Therefore, even if the reported income data were adjusted to reflect an equal sharing by husband and wife, the proportion of persons $6_{5}$ and over having less than $\$ 1,000$ would probably exceed half of the aged population.

Data for older families are similarly unfavorable. According to the Census Bureau, in 1959 (when fifty-five per cent of the aged persons reported less than $\$ 1,000$ ), half the 6 million families headed by a person 65 and over had less than $\$ 2,830$ and one-fourth had less than $\$ x, 620$. These incomes were for the support of 2.6 members, on the average-about two-fifths of them under 65 . The younger members often contributed a substantial share of the family's income.

Of the 3.6 million aged persons living alone or with nonrelatives, almost half had less than $\$ 1,000$ and four-fifths less than $\$ 2,000$ in 1959 . Counted in the figures for "persons," but not identified in the family income analysis are another 2.3 million aged persons (living in the home of a younger relative) who have less income than persons living in their own households and are seldom financially independent.

\section{Relative Income Needs}

To say that old people on the whole have low incomes is not in itself particularly meaningful. How much do they really need? There is, of course, no one answer. "Need" is a relative term, and it will vary with the specific case just as it does for younger families.

One measure of need is the Bureau of Labor Statistics budget designed to provide a "modest but adequate" level of living for a retired couple, in reasonably good health, keeping house alone in a rented dwelling in one of the 20 large cities-even 
though only a minority of the aged live in the circumstances described. The cost in late 1959 was estimated to range from $\$ 2,390$ to $\$ 3,370$, depending on the city and the concept adopted.

The median income of all elderly couples living alone in urban areas has been estimated at roughly $\$ 2,600$ to $\$ 2,800$ in 1959 . Thus, the cost of maintaining an elderly couple, in reasonably good health for their age and living alone in a rented dwelling in a large city, may have been beyond the reach of more than half of those who were in that category. Lowering the budget cost to a range of $\$ 2,200$ to 2,800 to allow for the estimated amount of housing costs that many of the couples would save as homeowners reduces the number of those for whom the budget standard would be more than income could provide, but this number would still be considerable. Furthermore, relatively few with incomes below the budget level would have sufficient cash savings or assets readily convertible to cash to make up the deficit.

Bureau of Labor Statistics estimates also indicate that it would have taken from $\$ \mathrm{r}, 4 \mathrm{IO}$ to $\$ \mathrm{r}, 835$ in late 1959 to maintain elderly persons living alone at the same standard as the budget couple. But the median income for individuals 65 and over living alone (or with nonrelatives) in cities was only $\$ \mathrm{r}, \mathrm{r} 40$ in 1959 .

When estimated costs for a comparable budget developed by the Bureau of Labor Statistics for a city worker's family of husband, wife and two children living at a "modest but adequate" level are converted to an adult-equivalent basis-considering the worker's I3-year old son as an adult, and the 8-year old daughter as half an adult-it appears that they are some ten to fifteen per cent less for the retired aged than for a young family. When income data for aged and younger families are likewise expressed in adult equivalents, it appears that the average income of aged persons (including those still at work) is some thirty-five per cent below that of these young families. ${ }^{42}$ Furthermore, the budget standard for the retired couple presumes they are in reasonably good health; any protracted illness or disability of either member and all terminal illnesses fall outside the scope of the budget.

\section{Other Resources}

Older persons as a group are more likely than young persons to have some savings, it is true. But most of their savings are tied up in their homes or in life insurance and are not readily convertible to cash. In general, moreover, those aged who have the smallest incomes and who would benefit most from other resources are the least likely to have them. This is almost as true of home ownership as it is with respect to financial assets.

The $195^{8}$ and 1959 surveys of Consumer Finances for the Federal Reserve Board found that among "spending units" headed by a person 65 and over, when income was less than $\$ 3,000$ only about forty-five per cent had liquid assets of $\$ 500$ or more,

\footnotetext{
¿U.S. Social Security Adm'n, Division of Program Research, Budget Needs of Aged and of Yodnger Worker Families, Research and Statistics note No. 12 (I96I).
} 
whereas when income was $\$ 3,000$ to $\$ 5,000$, in 1958 eighty per cent had liquid assets of that size, and in 1959 , seventy per cent.

In any case, for the aged taken as a group, holdings of savings readily convertible into cash are not very large. In rg6o, the Consumer Finances Survey found nearly two-fifths of the aged spending units with no money in bank accounts or savings bonds, or less than $\$ 200$. The picture would be even less favorable if one could include the one-fourth of all the aged who are not represented in the spending unit count, namely those living as part of a spending unit headed by a younger person, and those in institutions or other group quarters.

\section{Present Provisions for Meeting Health Costs}

\section{Voluntary Insurance}

Many aged persons have voluntary insurance which will assist them in case of serious illness requiring hospital care. In late 1959, according to data collected by the National Health Survey, forty-six per cent of the persons 65 years of age and over had hospital care insurance (the most prevalent form of health insurance). The same survey showed that sixty-seven per cent of the total population (sixty-nine per cent of those under 65 ) had some form of hospital care insurance. Those aged persons with health insurance were likely to be the most advantageously situated in general. When total family income of the person aged 65 and over (including both his own income and that of all other family members) was under $\$ 2,000$, only thirty-three per cent of the aged had hospital care insurance, while when the income was $\$ 4,000$ or more, fifty-nine per cent had such insurance. The younger persons among the aged group are more likely to have some protection against hospital care costs; fifty-three per cent of those $65-74$ as opposed to thirty-two per cent of those 75 and over. Those aged still in the work force are more likely to have health insurance protection than those already retired: sixty-four per cent as opposed to forty-two per cent. Those aged who are in relatively poorer health, at least as selfreported, are less likely to have health insurance. Fifty-three per cent of those reporting themselves as having no chronic conditions, or only conditions that did not curtail activity, had hospital care insurance-as opposed to thirty per cent of those reporting themselves as unable to carry on their major activity.

The coverage of aged persons by health insurance has been expanding at a more rapid rate in recent years than has coverage for the population as a whole. Survey data indicate a growth in hospital care insurance coverage, from July 1953 to late 1959 or January 1960, of forty-eight per cent for the aged population, while the corresponding growth for the total population was eighteen per cent. This more rapid growth rate has been used as a basis for the assertions that voluntary health insurance coverage of the aged will continue to expand at an accelerated rate. ${ }^{48}$ Based upon coverage trends by age group and by region, estimates by the Health

${ }^{3}$ See testimony for the Chamber of Commerce of the United States of America, Hearings 626-27. 
Insurance Association of America indicate that in 1969 between sixty and seventy-five per cent of the aged will have health insurance protection. ${ }^{44}$

The lower range of the Health Insurance Association of America estimate assumes that almost all the persons presently insured will continue to carry their insurance, and that there will be no net additions to the number insured. Such a statistical projection appears to be based on the least unreasonable set of assumptions. The expansion of health insurance coverage for the population as a whole is apparently reaching a saturation point, at about seventy-five per cent of the civilian population.5 If total health insurance enrollment remains at approximately this level, voluntary health insurance for the aged will expand somewhat, provided those presently insured continue to carry their health insurance when they retire. An assumption that all persons will continue to carry their insurance after they retire may well be unduly optimistic, however. Most members of the working force, with their families, are insured through group contracts at their places of employment. In the vast majority of cases, the employer is meeting part or all of the expense of the insurance. Unless these employer contributions are continued after retirement, the employee must assume the full cost of the insurance himself. It is unlikely that under these conditions, all retirees will maintain their coverage.

Although forty-six per cent of the aged had health insurance in late 1959, this is no real indication of the adequacy of such insurance, particularly in the face of serious illness requiring long-term hospital care. One measure of the relative adequacy of this insurance is indicated by the fact that, during the period from July I 958 to June $\mathrm{x} 960$, only fifty-nine per cent of persons aged 65 and over who were discharged from short-stay hospitals and who received any insurance payment toward their hospital bill, had three-fourths or more of that bill paid by insurance. ${ }^{46}$

The insurance industry is exploring possible avenues for extending the voluntary health insurance coverage of the aged. An example of these attempts to find new forms is the Connecticut 65 plan, designed to protect elder citizens against the catastrophic costs of serious or prolonged illness, and offered through the cooperative effort of the insurance companies doing business in Connecticut. The premiums are $\$ 84$ a year for the minimum offering: a program of limited major medical coverage with a \$100 deductible contribution, a \$5,000 lifetime maximum, and with eighty per cent of the covered costs after the \$Ioo deduction being met by the plan. For the major medical policy with a \$10,000 lifetime maximum, combined with a basic hospital-surgical plan, the premium is $\$ 204$ a year. Even this program

st Hearings 807-08.

$\approx$ According to the Health Insurance Couricil, whose estimates are generally higher than those based on household interviews, hospital care coverage rates for the past ten years have been as follows:

\begin{tabular}{|c|c|}
\hline $1951 \ldots \ldots 56.9 \%$ & $1956 \ldots \ldots 70.1$ \\
\hline $1952 \ldots \ldots 59.8$ & I957 $\ldots \ldots 72.1$ \\
\hline $1953 \ldots \ldots 62.4$ & $1958 \ldots \ldots 71.5$ \\
\hline I954 ....6.63.8 & $1959 \ldots \ldots 73.0$ \\
\hline $1955 \ldots \ldots 66.3$ & $1960 \ldots \ldots 73.4$ \\
\hline
\end{tabular}

${ }^{10}$ See U. S. Natronal Health SuRvey, Public Health Service, op. cit. supra note 4I. 
would not cover a large proportion of the average aged person's medical bill. These relatively high premium rates, beyond the financial reach of many aged, illustrate graphically the dilemma faced by private health insurance for the aged-the basic problem of a high risk group in which many do not have the financial means to carry their proportionate share of the risk through insurance.

\section{Public Programs}

Although most of the medical care used by aged persons is paid for privately or through health insurance, an important segment of this care is financed through public programs. The public programs for medical care of the aged take many forms. ${ }^{47}$ Some programs provide for all persons in special population groups irrespective of their ability to pay. Others focus more narrowly on the needy or the medically needy. At the federal level, emphasis has been placed upon expanding programs in this latter category to meet at least a portion of the more pressing medical care needs of the aged. Two programs are the vehicles for this: old-age assistance, and medical assistance for the aged.

From the beginning of the federal-state old-age assistance program, established by the Social Security Act of 1935, costs of medical care for old-age assistance recipients have been included in the costs which the federal government would share. Since 1950, federal matching of payments for medical care made directly to providers of care has been allowed. Additional emphasis has recently been placed upon medical care for old age assistance recipients in the provisions for increased federal matching of medical care payments by the Social Security Amendments of Ig60 and Ig6r.

It is significant, however, that in I 960 , of the fifty-four jurisdictions, ten states spent $\$ 30$ or more per month and thirteen spent $\$ 15$ to $\$ 30$, but there were thirty-one which spent less than $\$ 15$ per month for medical care for old age assistance recipients, including both vender payments and estimated money payments to recipients for medical care. Of the latter, three states made no such expenditure; and in the others, the average amounts ranged up from 44 cents per recipient. A study made by the Health Insurance Foundation found that private expenditures for medical care for a cross-section of persons aged 65 and over not in institutions averaged $\$ 14.75$ per month. Most expenditures for nursing home care were excluded because the study did not cover persons in nursing homes. All medical costs have increased since 1957-58. The medical needs of assistance recipients would be considerably greater, on the average, than those of the aged population as a whole. In consequence, either the thirty-one states which spent less than $\$ 15$ per recipient were meeting their medical needs through other means or the recipients were going without needed medical care. Analysis of available data on the arrangements for provision of medical care outside the assistance program to indigent and medically indigent persons suggests that while in some states the medical needs of public as-

\footnotetext{
${ }^{47}$ For a fuller description of these programs, see U. S. DeP'T of Health, Education, and WeLfare, op. cit. supra note 39 .
} 
sistance recipients are fairly well met, in a larger number of states public assistance and other available public and private resources together are failing to meet the needs of assistance recipients. ${ }^{48}$

The medical assistance for the aged program was established by the Social Security Amendments of Ig6o to assist the states in financing medical care for persons who do not qualify for old-age assistance but who cannot meet the cost of needed medical care. Under the program, federal funds are available to the states to help pay the costs of such care. States may choose among a broad scope of medical services in determining what medical service benefits will be provided in the state; the only significant limitation is that both institutional and noninstitutional care must be provided. As of November I3, Ig6I, twenty-one of the fifty-four jurisdictions had put medical assistance for the aged programs into effect, and seven had legislation enacted, but no plan had been submitted to the federal government. Three states had legislation in process. Three states with legislative authority were not expected to implement the program during $196 \mathrm{I}-62$. Two of the remaining twenty states have regular legislative sessions in I962. The other eighteen had their regular legislative sessions in I96I, and their legislatures adjourned without adopting a program. ${ }^{4 \theta}$ It is doubtful that any of these eighteen will consider medical assistance for the aged legislation during the short or special legislative sessions in Ig62.

Among the twenty-one states with programs in effect there was wide variety in eligibility requirements and in benefits provided. All provided in-patient hospital benefits, fourteen provided nursing home benefits, seventeen provided physicians' services, and eleven provided prescribed drugs. However, in most states benefits were subject to limiting maxima, stated in terms of number of days of care or visits authorized, the medical conditions covered, or the conditions under which the benefit would be provided. Only seven jurisdictions (Hawaii, Maryland, Massachusetts, New York, North Dakota, Puerto Rico, and the Virgin Islands) have relatively comprehensive medical programs providing hospital care, physicians' services, and prescribed drugs without major limitations. ${ }^{50}$

\section{III}

\section{The Debate}

While there is general agreement that a need exists for some sort of health protection for aged persons, there are real differences of opinion as to the scope of this need and as to the proper means for meeting it. The delegates to the White House Conference on Aging represented the full range of views. In describing the Conference, however, Robert W. Kean, Chairman of the National Advisory Commit-

«II., chs. I and III.

${ }^{10}$ U.S. Bureau of Public Assistance, Dep't of Health, Education, and Welfare, Special Weekly Report, Nov. 13, I96x.

${ }^{\circ}$ U.S. Bureau of Public Assistance, Dep't of Health, Education, and Welfare, Summary Information on New Programs of Medical Assistance for the Aged (I96I). 
tee for the Conference, stated with reference to the health and medical care of older citizens:

The basic convictions of all Conference sections that studied this subject were that: (a) the physical well-being of America's older citizens is a legitimate concern of Federal, State and local governments, as well as the private groups and individuals of the country; (b) all public and private elements of our society must expand and coordinate their efforts to improve the physical well-being of older persons; (c) our medical and scientific professions must continue and augment their efforts to improve the health of our older citizens, and must improve the quality and quantity of medical services rendered to them; (d) every older citizen is entitled to adequate medical care, and if he cannot pay for this himself, our society must provide it to him; and (e) every older person must have some protection against the high cost of catastrophic or long-range illness.51

That there is general agreement on these basic propositions is illustrated by the testimony before the House Committee on Ways and Means in July-August I961. Secretary Ribicoff, testifying in support of the President's proposal, stated as a foundation of his position that the "high costs of medical care for the aged are going to be paid for in this country." He observed further: "The issue is not whether to pay these costs. The only issue is how to pay them." ${ }^{\text {"2 }}$ The representative of the Health Insurance Association of America also supported this general propostion when he said:

We favor the best possible health care for our entire population, including all of the older segment. For some 25 years the insurance industry has devoted tremendous energy to the development of broad and effective means to provide for financing the costs of the best possible health care in the world. I am sure that is the objective of those who support H.R. 4222 (the Administration's health insurance for the aged proposal). Therefore, our differences arise only as to the means and the ultimate effect of the various means of accomplishing this purpose for our older citizens. ${ }^{53}$

The issue becomes joined, therefore, not on the question of whether health care for the aged will be paid for, but on how this is to be done. The development of a general public acceptance that health care, while essentially involving the individual, is a matter of public concern, is attested in the general belief that the United States must somehow develop a combination of public and private activity which makes health protection available for all. There is now a widespread feeling that no person should be deprived of medical care because he cannot afford it. In other words, medical care is becoming accepted, not as an economic good whose availability to any single individual depends upon his ability to purchase it, but as a citizen's right, in the same sense as the right to education.

That this feeling accepts the proposition that government should be concerned with assurance of care reflects in part the important role of government in various aspects of the health and medical picture. In particular, the federal government has

${ }^{51}$ Kean, Guidelines for Action-The White House Conference on Aging, State Government, Spring 196r, p. 133 .

${ }^{2}$ Hearings 26.

Id. at 784 . 
become increasingly involved in financing both medical research and the construction of hospitals and other health facilities since World War II. It is natural that the federal interest extends from this concern with the "what" and the "where" to an equally strong concern for the delivery of medical care.

The system of medical care which exists illustrates the pluralistic nature of American solutions to many basic problems. It is a quilt made up of many elements, from public activity to private prepayment mechanisms, from philanthrophy to individual purchase. The facts of the case indicate that for many aged persons, adequate basic health care protection does not now exist and will not be achieved through private action alone. The debate on financing health care for the aged therefore now divides between those who believe that basic protection should be provided through a broad public program and those who believe that the proper role of the government lies in picking up the health care burden for those aged who cannot carry it. The proponents and opponents of social-insurance-based health care have advanced many arguments, some of which tend to obscure the real issues.

\section{A. Summary of Arguments}

The major arguments advanced in favor of a health insurance program for old-age and survivors insurance beneficiaries are: (a) that voluntary health insurance can never meet the needs of the aged, since they are and will continue to be a highrisk group combining low income with high medical care and facility use rates; (b) that a lifting of this high-cost load from private health insurance will enable the latter to do a more acceptable job of meeting the needs of the rest of the population; (c) that, in general, more extensive and more adequate protection can be provided for all or most of the aged through a public program or programs; (d) that the social insurance mechanism provides an equitable way of spreading the cost of medical care in old age over an individual's working lifetime; (e) that under such a program the dignity of the individual would be preserved; $(f)$ that it would help aged persons remain self-reliant; and (g) that financial considerations would no longer stand in the way of an aged beneficiary seeking the covered services which he needs.

On the other hand, those opposed to the proposed program argue (a) that voluntary health insurance coupled with individual resources can provide adequate protection for most of the aged, and those who need care beyond this may obtain it from existing public programs; (b) that however limited the program as originally enacted, it will later be expanded to cover other medical services; (c) that a program for the aged will inevitably be expanded to cover the remainder of the population, and is therefore a foot in the door for socialized medicine; (d) that the federal government will intrude into the doctor-patient relationship; (e) that the costs of the program are difficult to estimate and will exceed those projected by the government on the basis of current practices and experience; and ( $f$ ) that, in any case, the proposed program does not cover all the aged, but only those eligible for 
old-age and survivors' insurance benefits, and therefore leaves out those who are most needy.

\section{B. The Straw Men}

The most persistent argument raised against health insurance for the aged under social security is that this program merely represents a "foot in the door," a base from which the cancer of "socialized medicine" will creep to cover all Americans and the entire land. ${ }^{54}$ This argument flies in the face of the trend in providing health care in this country and the disavowals of those who formerly supported compulsory national health insurance. In addition, in its attempt to pull the necessary emotional strings to block the measure, this argument completely obscures the fact that extension of the program would depend upon action by the Congress, and that such action would probably come only in the face of a need for federal financing of all health care so overwhelming that it would be enacted irrespective of whether a health insurance for the aged program existed.

The validity of the contention by the American Medical Association that the proposed program would lead to "socialized medicine" is also questioned by many because of the Association's long history of crying "socialized medicine" whenever measures not to the liking of its officers have been under consideration. In I930, for example, the Association condemned as "unsound in policy, wasteful and extravagant, unproductive of results and tending to promote communism" the SheppardTowner Act to provide federal grants to aid states in reducing infant and maternal mortality. ${ }^{55}$ Later in the I930's voluntary health insurance, now so dear to the heart of the Association, was designated as socialistic. ${ }^{56}$

A second argument used against the proposed program is that the estimated cost is too low, and that the program will cost more than the tax provision would raise. ${ }^{57}$ This argument, apparently intended to raise doubts about the financial soundness of the old-age survivors and disability insurance program if health insurance is added, fails to recognize that if the benefits provided under the program are needed for the health care of the beneficiaries, then their costs must be met in one way or another. The question, then, revolves not around whether the cost estimates are correct, but whether the services proposed are reasonable ones for inclusion under this social insurance system. While it is true that a program severely limited in the scope of services provided might encourage some over-utilization of those particular services, there is actually very little information bearing on this matter, particularly for the aged.

Supporters of health insurance for the aged, on the other hand, argue that the

4t See, for example, the statement of the American Medical Association before the House Ways and Means Committee on H.R. 4222, Hearings $1340-42$.

${ }^{5}$ American Medichl Ass's, Digest of Official Actions, I846-r958, at 92 (1959).

${ }^{\mathrm{s}}$ Tollen, Financing Medical Care for the Aged, Social Work, April r96r, p. 8. See also, id. at 7-10, for summary with citations of the A.M.A. position on a long series of issues.

${ }^{87}$ See, for example, the cost estimates in the Health Insurance Association of America's testimony, Hearings $785-86$. 
social insurance system is the only practical way of enabling most people to pay during their working years toward meeting the health costs which they will face in old age. Although this statement is technically true, it implies that a person pays as he works for health insurance in which he has a vested, paid-up right when he reaches age 65. It thus clouds over the fact that the benefits would, in the tradition of social security, be provided for the present aged who have not contributed. The emphasis on individual contributions toward protection disguises to some extent the fact that the financial base of this program is a tax on employers and employees which is used in the main to provide benefits for the aged at the time the tax is being collected, although there is some funding. In contrast to commercial insurance which must be fully funded so that it need not depend on new policyholders to maintain its solvency in the future, a national social insurance program that covers virtually the entire population (not only now but throughout the future) and is backed by the taxing power of the United States government not only need not be fully funded but would create serious fiscal and economic problems if it were.

\section{The Real Issue}

The real debate revolves around the question of national responsibility and the role of the federal government. The fact that the need for health care and the inability of most aged persons to meet its potentially heavy costs are much the same irrespective of residence suggests that any solution to this problem must be nationwide in scope. Since a relatively small proportion of all aged persons can be sure of the resources to meet the heavy costs of serious illness, a presumptive need can be established for the entire aged group. This would obviate individual demonstration of need. Thus, a national program covering all the aged would appear to offer the only means of assuring to the aged that the designated health care benefits will be available when needed. It would at the same time help to prevent dependency, making it unnecessary for many aged persons who have been self-supporting all their lives to turn to assistance in old age because of medical care expenses.

It is therefore logical to look to the established basic program for income maintenance of the same group, and to add health insurance to that program. Financing through an increment in the earmarked tax now used to finance monthly cash benefits could provide the funds required for a program of any particular specifications without subjecting it to the pulling and hauling of the general budgeting process and to competition with other national programs for general revenue funds. This is not to say, however, that with a basic health insurance program as a primary resource, public assistance would not continue to be necessary as a second line of protection in meeting medical care costs as it is also in income maintenance.

Use of the social insurance system would mean that a large number of the present aged are not eligible for health insurance benefits since they are not eligible for cash benefits. The supporters of the social insurance approach, with the ex- 
ception of Senators McNamara and Javits, have evaded this question by focusing their attention on the future coverage of the system. They believe, however, that the Medical Assistance for the Aged program, relieved of the responsibility of providing basic care for old-age and survivors insurance beneficiaries, will be better able to meet the medical needs of those aged persons who are not eligible under the social insurance programs.

To be avoided in any national program of health insurance for the aged is the development of the program in such a way as to lower the quality of care provided. This could result from pressure on available facilities and services, but other programs designed to expand capacity simultaneously are either under way or have been proposed. Some ${ }^{58}$ fear also that officials responsible for administering the program might, in an effort to hold down costs, attempt to influence the type of care provided without having appropriate medical knowledge. The present bill (H.R. 4222) has been drafted to minimize this latter possibility. Indeed, proponents point, rather, to the added substance which the program would give to the freedom of the physician and patient together to select the care which the patient needs by allowing the physician to place his patient in a hospital whenever it is necessary, without fear of the economic consequences to the patient. In any case, a fear of interference does not seem an adequate objection to a needed program, but rather an invitation to cooperate in the program in such a way as to forestall the effect feared.

A concomitant of fear of interference is the consideration of the nature of the benefits which should be provided under a health insurance proposal. Essentially, since the first proposals were made in 1952, this has been seen as basically a hospital benefit program. Hospital care involves the greatest cost burden for the person who needs these services. In addition, it is in this area that the experience of voluntary health insurance provides the most complete pattern of experience from which the government may draw. The program has thus been viewed primarily from the point of view of insurance and insurable risks rather than as a medical care program. If the latter were the emphasis, the program would probably concentrate on physicians' services and preventive, diagnostic, and early treatment care, rather than on long term hospitalization and its alternatives.

The essential difference between those who favor and those who oppose the extension of the social insurance system to include health insurance revolves around viewpoints going much deeper than the issue immediately involved. Those who oppose this addition to federal activity look upon the national government as a distant stranger, to be called upon in the very last instance. In their view, the proper means for meeting the need is reliance first upon the individual, then the local community, then the state, and only as a last resort the federal government. The actions of government are seen as severe limitations upon the freedom of individuals, in this case an "inexorable forcing of coverage upon Social Security beneficiaries

\footnotetext{
Es See, for example, the statement of the American Medical Association, in Hearings, 1317-26.
} 
regardless of need or personal choice." ${ }^{\text {"59 }}$ This viewpoint is reflected by the American Medical Association. As stated in the testimony of its representatives before the House Committee on Ways and Means, ${ }^{60}$

We recognize that there are certain persons who have a special claim on the Federal Government-either as employees, wards, members of the uniformed services, or veterans disabled in the service of the Nation. We do not believe the aged, who would be covered under this legislation, have such a claim on the Federal Government, or that a compulsory payroll tax should be imposed to provide benefits for millions of older people who do not need or want Federal help.

Embodied in support for health insurance for the aged under social security, on the other hand, is a view of the nation as a single community, at least as regards certain broad desires and needs of its citizens. In this view the national government is seen as representing the organized community at work. Federal government action is therefore the most logical to meet a widespread and intense social need. For supporters of the program, federal activity is "us" moving toward certain goals, rather than "they" imposing unwarranted restraints upon the citizenry.

If this basic difference in point of view toward the federal government is resolved in favor of a national community, at least as regards health insurance for the aged, it will be possible to develop programs which provide health care protection adequate to meet the basic needs without doing violence to the values inherent in the existing patterns of medical care.

\section{ADDENDUM}

Since this article was completed in late November I96r, four new bills of importance relative to financing of medical care for the aged have been introduced in the Eighty-seventh Congress, Second Session (S. 2664, H.R. 105I3, H.R. 10755 and H.R. II253) and certain new statistics have become available relating to the health care costs of the aged, the relative incomes of old and young families, and developments in provision of medical care under the public assistance programs.

The new data, summarized in the report, The Health Care of the Aged: Background Facts Relating to the Financing Problem, released by the U. S. Department of Health, Education and Welfare in May 1962, confirm the impression conveyed by earlier statistics of greater medical need and more limited resources among the aged than the young, and of the limitations of the public assistance approach.

Two of the four new major bills would use the social security system as the basic means for financing health insurance benefits. S. 2664, introduced by Senator Jacob Javits, would provide "retired" aged persons not receiving medical care through the public assistance program with a choice of several health insurance benefit possibilities, with benefits for social security beneficiaries financed by an increase in the payroll tax and those for persons not eligible for such benefits from federal

${ }^{20}$ Statement of National Association of Manufacturers, in Hearings I7 $^{86}$.

${ }^{\mathrm{c}}$ Hearings $\mathrm{1} 3 \mathrm{I} 6$. 
general revenues. H.R. Ir253, introduced by Congressman Lindsay, modifies the health insurance program proposed by the Administration to allow beneficiaries to "elect out" from coverage if they have a qualified private health benefits plan and to allow states, with federal participation, to "buy in" for aged persons not eligible for social security benefits. On the other hand, H.R. ro755, introduced by Congressman Bow, would use the income tax mechanism to distribute a federal subsidy of up to \$125 per aged person toward the purchase of private health insurance which provides certain federally-established minimum benefits. The Durno bill, H.R. I0513, would establish a National Advisory Medical Commission to study the proper role of the federal government in providing medical care for the aged, and to report to the Congress by January $3 \mathrm{x}$, 1963 . 